\title{
R269C variant of ESR1: high prevalence and differential function in a subset of pancreatic cancers
}

Tomer Boldes ${ }^{1,2+}$, Keren Merenbakh-Lamin 1,2†, Shani Journo ${ }^{1,2}$, Eliya Shachar ${ }^{1}$, Doron Lipson ${ }^{3}$, Adva Yeheskel ${ }^{4}$, Metsada Pasmanik-Chor ${ }^{4}$, Tami Rubinek ${ }^{1,2}$ and Ido Wolf ${ }^{1,2^{*}}$ (I)

\begin{abstract}
Background: Estrogen receptor a (ESR1) plays a critical role in promoting growth of various cancers. Yet, its role in the development of pancreatic cancer is not well-defined. A less studied region of ESR1 is the hinge region, connecting the ligand binding and DNA domains. rs142712646 is a rare SNP in ESR1, which leads to a substitution of arginine to cysteine at amino acid 269 (R269C). The mutation is positioned in the hinge region of ESR1, hence may affect the receptor structure and function. We aimed to characterize the activity of R269C-ESR1 and study its role in the development of pancreatic cancer.
\end{abstract}

Methods: Transcriptional activity was evaluated by E2-response element (ERE) and AP1 -luciferase reporter assays and GRT-PCR. Proliferation and migration were assessed using MTT and wound healing assays. Gene-expression analysis was performed using RNAseq.

Results: We examined the presence of this SNP in various malignancies, using the entire database of FoundationOne and noted enrichment of it in a subset of pancreatic non-ductal adenocarcinoma $(n=2800)$ compared to pancreatic ductal adenocarcinoma (PDAC) as well as other tumor types (0.53\% vs $0.29 \%, p=0.02)$. Studies in breast and pancreatic cancer cells indicated cell type-dependent activity of ESR1 harboring R269C. Thus, expression of R269C-ESR1 enhanced proliferation and migration of PANC-1 and COLO-357 pancreatic cancer cells but not of MCF-7 breast cancer cells. Moreover, R269C-ESR1 enhanced E2-response elements (ERE) and AP1-dependent transcriptional activity and increased mRNA levels of ERE and AP1-regulated genes in pancreatic cancer cell lines, but had a modest effect on MCF-7 breast cancer cells. Accordingly, whole transcriptome analysis indicated alterations of genes associated with tumorigenicity in pancreatic cancer cells and upregulation of genes associated with cell metabolism and hormone biosynthesis in breast cancer cells.

\footnotetext{
* Correspondence: idow@tlvmc.gov.il

This work was performed in partial fulfillment of the M.D. thesis

requirements of the Sackler Faculty of Medicine, Tel Aviv University.

${ }^{\dagger}$ Tomer Boldes and Keren Merenbakh-Lamin contributed equally to this

work.

'Institute of Oncology, Tel Aviv Sourasky Medical Center, 6423906 Tel Aviv,

Israel

${ }^{2}$ Sackler Faculty of Medicine, Tel Aviv University, 6997801 Tel Aviv, Israel

Full list of author information is available at the end of the article
}

(c) The Author(s). 2020 Open Access This article is licensed under a Creative Commons Attribution 4.0 International License, which permits use, sharing, adaptation, distribution and reproduction in any medium or format, as long as you give appropriate credit to the original author(s) and the source, provide a link to the Creative Commons licence, and indicate if changes were made. The images or other third party material in this article are included in the article's Creative Commons licence, unless indicated otherwise in a credit line to the material. If material is not included in the article's Creative Commons licence and your intended use is not permitted by statutory regulation or exceeds the permitted use, you will need to obtain permission directly from the copyright holder. To view a copy of this licence, visit http://creativecommons.org/licenses/by/4.0/ The Creative Commons Public Domain Dedication waiver (http://creativecommons.org/publicdomain/zero/1.0/) applies to the data made available in this article, unless otherwise stated in a credit line to the data. 
(Continued from previous page)

Conclusions: Our study shed new light on the role of the hinge region in regulating transcriptional activity of the ER and indicates cell-type specific activity, namely increased activity in pancreatic cancer cells but reduced activity in breast cancer cells. While rare, the presence of rs142712646 may serve as a novel genetic risk factor, and a possible target for therapy in a subset of non-ductal pancreatic cancers.

Keywords: Pancreatic cancer, Estrogen receptor, Activation Function-1, SNP

\section{Background}

The human estrogen receptor $\alpha(E R \alpha)$, encoded by ESR1, is a member of the steroid/nuclear receptor superfamily and functions as ligand-activated transcription factors [1]. Upon binding of estrogen, the ER dimerizes and binds to coactivators. The complex is then recruited to the estrogen-responsive elements (ERE) on the promoters of ER target genes. The major functional domains of ER $\alpha$ are the N-terminal Activation Function-1 (AF-1) which modulates transcription, the DNA-binding domain (DBD) and the ligand-binding domain (LBD) that contains Activation Function-2 (AF-2) [2]. A less characterized domain of ER $\alpha$ is the hinge region, which lies between the DBD and the LBD. The hinge region contains putative nuclear localization sequence (NLS) and may play a role in transcriptional regulation $[1,3-6]$.

Approximately $75 \%$ of all breast cancers express ER $\alpha$, and targeting ER $\alpha$ signaling, is a key treatment strategy in these tumors. ER $\alpha$ plays a major role in the development of other malignancies, including endometrial and ovarian cancers [7] and is expressed in subsets of additional tumors, including lung [8] gastric [9] and colon [10] cancers. Pancreatic cancer is the fourth leading cause of cancer death, with five-year survival of roughly $8 \%$ [11]. Known risk factors for pancreatic cancer include smoking, diabetes, obesity and pancreatitis [12] and up to $10 \%$ of the cases are attributed to high-risk inherited mutations $[13,14]$. Yet, initiating genetic mechanisms leading to the development of pancreatic cancer are mostly unknown. Pancreatic ductal adenocarcinoma (PDAC) is the most common histological subtype of pancreatic cancer, representing $85 \%$ of all pancreatic neoplasms while less common subtypes include adenosquamous, mucinous, anaplastic and signet ring cancers [15]. Interestingly, ER $\alpha$ is also expressed in a subset of pancreatic adenocarcinoma, most notably in mucinous tumors [16-19] and in vitro and in vivo studies indicated growth inhibition of pancreatic cancer cells by tamoxifen [20,21]. Several clinical trials reported on activity of hormonal therapy in pancreatic cancer [22-28] including a prospective randomized trial that reported on median survival of 5.3 months among 37 tamoxifen-treated patients, compared to 3 months in 39 patients treated with a placebo, with marginal statistical significance $(p=0.07)$ [29]. Yet, no benefit was noted in a smaller trial [30].

A documented rare SNP in the ESR1 gene (rs142712646) leads to a substitution of arginine at position 269 of the hinge region to cysteine (R269C). To our knowledge, the activity of this SNP, and its potential role in tumorigenesis, has not been reported yet. We report here on enrichment of this functional variant in non-PDAC pancreatic cancers. In this study, we aimed to characterize the activity of R269C-ESR1 in pancreatic and breast cancer cells and identify its role as a potential driver of proliferation of pancreatic cancer cells. Functional analysis revealed increased AP-1 dependent geneexpression of this variant in pancreatic but not in breast cancer cells, and expression of the R269C variant enhanced proliferation and migration of pancreatic cancer cells. These data indicate unique, cell-type dependent activity, of R269C and its contribution to tumor aggressiveness in a small subset of pancreatic cancers.

\section{Methods}

\section{Foundation medicine database analysis}

We searched for mutations in the ESR1 gene, in the entire database of the Foundation One clinical database (Foundation One, Foundation Medicine, Cambridge, MA). The database consists of $>100,000$ cases, of them $>4000$ PDAC cases and 2800 non-PDAC pancreatic cancer. The test has been described previously [31] and consists of deep sequencing of cancer-related genes on DNA extracted from paraffin embedded tissue samples.

\section{Computational structure analysis}

The secondary structure of ER $\alpha$ was predicted using ConSSert [32], PsiPred [33], Jnet [34] and Predator [35]. A multiple sequence alignment of Human ER $\alpha$ and other 38 vertebrates homologs, collected from SwissProt, was calculated using Mafft [36]. The alignment and secondary structure annotations were presented in Jalview [37]. Known domains of ER $\alpha$ were taken from Pfam [38].

\section{Reagents and antibodies}

$17 \beta$-Estradiol $\left(\mathrm{E}_{2}\right)$ and crystal violet were obtained from Sigma (St. Louis, MO); ICI 182,780 from Tocris Bioscience (Ellisville, MO), G418 from Life Technologies (Waltham, MA); qScript cDNA SuperMix and PerfeCTa SYBR Green FastMix from Quanta BioSciences (Gaithersburg, MD). Primers synthesis- IDT (Coralville, IA). 


\section{Plasmids and constructs}

The ERE-luciferase reporter construct, kindly provided by D. Harris, (UCLA, CA), consists of 2 repeats of the upstream region of the vitellogenin ERE promoter. pRL Renilla luciferase control was purchased from Promega (Cat no E2261, Promega, Madison, WI). The generation of WT-ER construct (in pcDNA3) was described elsewhere [39]. Arginine to cysteine mutation (R269C-ER) was inserted using WT-ER as a template (generated by GeneScript Inc. HK, China).

\section{Cells and transfection}

Human kidney cell line HEK293, breast cancer cell line MCF-7 and pancreatic cancer cell lines COLO-357 and PANC-1 were obtained from ATCC (Manassas, VA). All cells were maintained in Dulbecco's modified Eagle's medium (DMEM), containing 10\% fetal bovine serum and $100 \mathrm{U} / \mathrm{ml}$ penicillin/streptomycin $(1 \%)$ at $37^{\circ} \mathrm{C}$ in a humidified 5\% CO2 atmosphere. All experiments were conducted with cells under 15 passages. For estrogen studies, cells were cultured in phenol-free media using $10 \%$ charcoal-treated serum (Beit Haemek, Israel) for 2 days before treatment. All transfections were conducted with Jet PEI (Polypus Transfection, Illkirch, France) according to the manufacturer's instructions.

\section{Luciferase assays}

The assays were conducted essentially as described [4042]. In brief, cells grown in phenol-free media using $10 \%$ charcoal-treated serum were plated in 96-well plates, and transiently transfected with the constructs (WT-ER or R269C-ER), reporter vector (ERE-luciferase or AP-1 luciferase) and Renilla vector. Twenty-four hours later cells were treated with $10 \mathrm{nM}$ E2 or a $0.0003 \%$ ethanol as a control vehicle for the ERE-luciferase assay or with ICI 182780 or $0.001 \%$ DMSO as a control vehicle for the Ap-1-luciferase assay [43]. At indicated times Dual-Glo Luciferase (Promega) reagent was added to the medium then the cells were incubated at $25^{\circ} \mathrm{C}$ for $30 \mathrm{~min}$ afterwards the firefly luminescence was measured by multichannel plate spectrophotometer. After the first reading, Dual-Glo ${ }^{\oplus}$ Stop \& Glo (Promega) reagent was added to the plate, cells were incubated at $25^{\circ} \mathrm{C}$ for $30 \mathrm{~min}$, then Renilla luminescence was measured similarly. Luciferase activity was normalized by calculating the ratio of Firefly to Renilla luciferase units.

Quantitative real time reverse transcription-PCR (qRT-PCR) Two days after transfection with the different constructs, total RNA was prepared using the High Pure RNA Isolation Kit Roche (Roche). Total RNA $(1 \mu \mathrm{g})$ was reverse transcribed using qScript cDNA synthesis kit (Quanta Biosciences). Quantitative RT-PCR (qRT-PCR) was used to determine mRNA level. Primers were designed using
Primer Express (Applied Biosystems, Foster City, CA, USA) and synthesized by IDT (Coralville, IA). Primers used: GREB1a (human): F 5'-ACGTGTGGTGACTG GAGTAGC, R 5'- CCACGCAAGGTAGAAGGTGA; TGF- $\alpha$ (human): F 5' - CCCGCTGAGTGCAGACC, R 5' ACGTACCCAGAATGGCAGAC; CyclinD-1 (human): F 5' - TGGAGGTCTGCGAGGAACAG, R 5' - AGCTGC AGGCGGCTCTTT; IGF-1R (human): F 5' - ATGTCC AGGCCAAAACAGGAT, R 5'- CAACCCTCCCACGA TCAACA. Equal loading was determined using $\beta$-actinspecific primers. Amplification reactions were performed with Platinum qPCR SuperMix in triplicate using StepOne Plus (Applied Biosystems). PCR conditions: $50^{\circ} \mathrm{C}$ for 2 min, $95^{\circ} \mathrm{C}$ for $2 \mathrm{~min}$, followed by 40 cycles of $95^{\circ} \mathrm{C}$ for 15 $\mathrm{s}, 60^{\circ} \mathrm{C}$ for $45 \mathrm{~s}$.

\section{Migration assay}

Migration was assessed using the wound-healing ("scratch") assay. COLO-357, PANC-1 and MCF-7 cells were grown to confluency in 6-well plates, with the various constructs (pcDNA3, WT-ER or R269C-ER) and grown in phenol-free media with $10 \%$ charcoal-treated serum for $24 \mathrm{~h}$. Cells' monolayer was scraped in a straight line with a $200 \mu \mathrm{L}$ sterile pipette tip for $48 \mathrm{~h}$. The cells were photographed at 0,24 , and $48 \mathrm{~h}$ with an inverted phase-contrast microscope (Olympus, Tokyo, Japan). Calculation of cell migration (d) was determined using the equation $=\frac{m 1-m 2}{2}$, when $\mathrm{m} 1$ is wound width at time 0 and $\mathrm{m} 2$ at 24 or $48 \mathrm{~h}$.

\section{Western blot analysis}

Cells were washed twice with PBS, snap frozen in liquid nitrogen and stored at $-80^{\circ} \mathrm{C}$ until the analysis. Cells were harvested and lysed for total protein extraction in radioimmunoprecipitation assay (RIPA) buffer $(50 \mathrm{mM}$ Tris- $\mathrm{HCl}$, pH 7.4, 150 mM NaCl, 1\% NP-40, 0.25\% Na-deoxycholate, 1 mM EDTA, $1 \mathrm{mM} \mathrm{NaF}$ ) together with a protease inhibitor cocktail (Sigma). A total of $50 \mu \mathrm{g}$ protein extracts were loaded on $10 \%$ polyacrylamide gels, separated electrophoretically and blotted from the gel onto nitrocellulose membrane (Schleicher \& Schuell Bioscience GmbH, Dassel, DE, USA). The membranes were blocked with skim milk $1 \%$ in PBS-T (0.01 M Tris- $\mathrm{HCl} \mathrm{pH} \mathrm{-7.6,} \mathrm{0.15} \mathrm{M} \mathrm{NaCl,} \mathrm{0.2 \%} \mathrm{Tween} \mathrm{20)} \mathrm{for}$ an hour, and then immunoblotted overnight with the indicated antibodies. $\beta$-actin antibody was used as loading control. Membranes were washed 5 times with TBS-T, followed by incubation with horse raddish peroxidase (HRP, Jackson Immuno Research, West Grove, PA) conjugated antibodies and were detected by using enhanced chemiluminescence (ECL) reaction.

\section{Proliferation assay}

3-(4,5-dimethylthiazol-2-yl)-2,5-diphenyltetrazolium bromide (MTT) assay was conducted essentially as described [44]. In 
brief, cells were counted and plated in 96-well plates (5000 cells/well), and transiently transfected with WT-ER, R269CER or an empty vector then cultured in phenol-free media with 10\% charcoal-treated serum. Twenty-four hours later cells were treated with E2 $(10 \mathrm{nM})$ or $0.0003 \%$ ethanol as a control vehicle and at indicated time points MTT reagent was added to the medium $(500 \mu \mathrm{g} / \mathrm{ml})$. Cells were incubated for $1.5 \mathrm{~h}$, afterward medium was removed, $100 \%$ DMSO was added and absorbance was determined at a wavelength of $570 \mathrm{~nm}$ using a multichannel plate spectrophotometer.

\section{RNAseq}

MCF-7 or COLO-357 cells were seeded in phenol red depleted medium with charcoal stripped serum. Cells then were transfected with either WT-ER or R269C-ER in triplicates and then treated with vehicle control or E2 $(10 \mathrm{nM})$ for $24 \mathrm{~h}$. Total RNA was extracted using the High Pure RNA Isolation Kit (Roche, Mannheim, Germany). RNAseq and bioinformatics were conducted at the Tel-Aviv University Genomics Research Unit and Bioinformatics Unit (Tel-Aviv, Israel). The libraries were prepared using NEBNext ${ }^{\circ}$ Ultra $^{\mathrm{Tm}}$ II RNA Library Prep Kit for Illumina ${ }^{\circ}$ (New England Biolabs ${ }^{\circledR}$ inc., 240 County Road Ipswich, MA). For sequencing: briefly, $1000 \mathrm{ng}$ of total RNA were fragmented followed by reverse transcription and second strand cDNA synthesis. The double strand cDNA was subjected to end repair, A-base addition, adapter ligation and PCR amplification to create barcoded libraries. Libraries were evaluated by Qubit and TapeStation. Sequencing was conducted with NextSeq 500/550 v2.5 (Illumina) at 75-cycles, Single Read kit. The output was $\sim 21$ million reads per sample.

\section{Bioinformatics}

Poly-A/T stretches and Illumina adapters were trimmed from the reads using cutadapt; resulting reads shorter than $30 \mathrm{bp}$ were discarded. FastQ files were uploaded to Partek Flow [45] for processing. Reads were mapped to the Homo

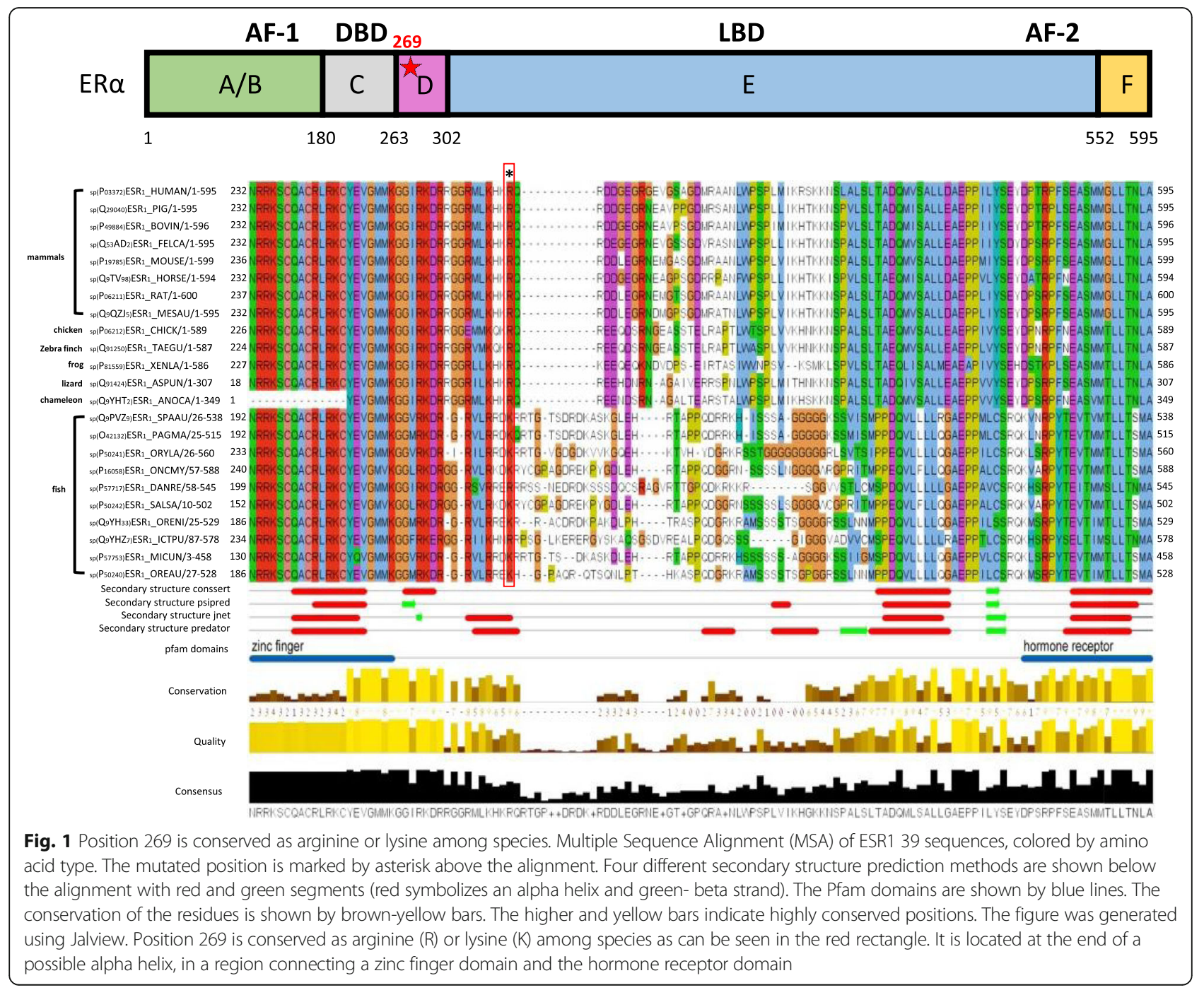


sapiens GRCm38 reference genome using BWA-MEM [46] (with default parameters). Quantification to annotation model was performed using Partek E/M [47] and RPKM normalized expression levels for each gene were obtained. Differentially expressed genes were identified using GSA (Genome specific analysis) [48, 49]. Pathway and function enrichment were analyzed using specified webtools and heatmaps of genes associated with specific pathways were generated using Partek Genomic Suite [50].

\section{Statistical analysis}

Each experiment was performed at least three times. The data were expressed as the mean \pm SD or SE. Statistical significance was assessed by Student's $\mathrm{t}$ test. A $P$ value of $<0.05$ is considered statistically significant.

\section{Results}

Prevalence of R269C substitution in ESR1 in clinical samples of pancreatic cancer

The substitution of $\mathrm{C}$ to $\mathrm{T}$ at position 1039, leading to a substitution of arginine at position 269 to cysteine (R269C), was observed in a patient with mucinous pancreatic adenocarcinoma conducting tumor genomic analysis for clinical purposes. This substitution is a known rare SNP (rs142712646) [51] and its frequency among
European population is estimated to be $0.14 \%$ according to the ExAC dataset. Following this observation, the frequency of this alteration was examined on the entire clinical database of FoundationOne, containing >150,000 tumor samples of various origins. The observed frequency in a wide range of malignancies, including breast and pancreatic ductal adenocarcinoma, was $0.29 \%$ and was considered to be similar to the frequency at the ExAC dataset. Yet, a significantly higher frequency was noted in $\sim 2800$ non-PDAC pancreatic cancer $(0.53 \%, p=0.02)$. This enrichment suggests that the $\mathrm{R} 269 \mathrm{C}$ substitution may play a role in the development of these tumors.

Structural analysis of ESR1 harboring the R269C alteration R269 lies within a potential nuclear localization sequences (NLS), known as p-NLS2 [52, 53]. Analysis of Swissprot database indicated position 269 to be highly conserved among species as either arginine or lysine (Fig. 1). Structural analysis using four different secondary structure prediction tools (described under Materials and Methods) suggests that it is located at the end of a possible $\alpha$-helix, in a region connecting a zinc finger domain and the hormone binding domain. Thus, R269 is predicted to be in contact with residues from the DNA binding domain and the steroid binding domain, and as

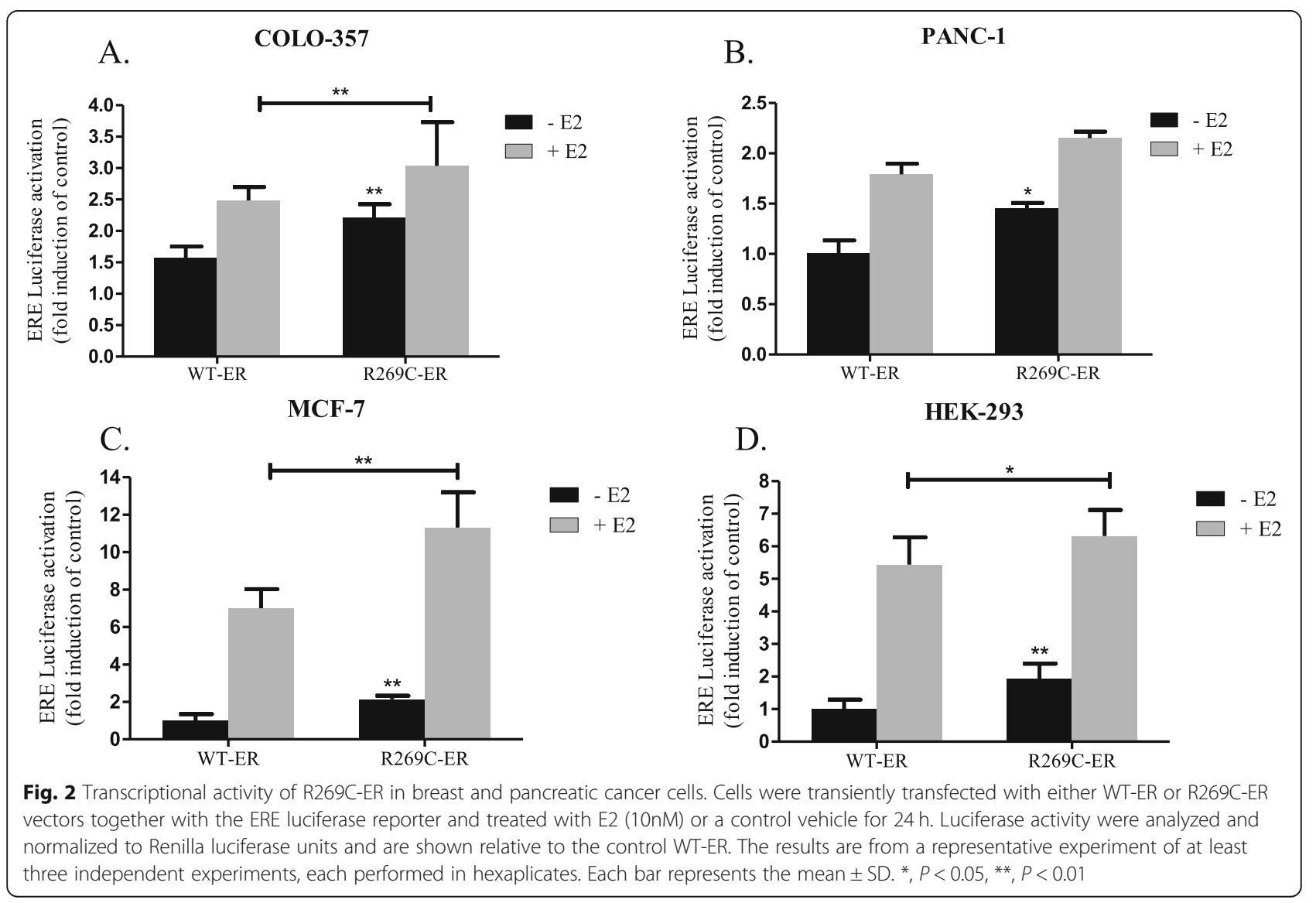


arginine $(\mathrm{pKa}=12.5)$ is positively charged at physiological $\mathrm{pH}$, the substitution to cysteine would result in a change from a positive charge to a more negative one at position 269. Moreover, it may lead to the formation of wrong SS bonds in the zinc finger domain, containing several conserved cysteine residues.

\section{Increased estrogen-dependent transcriptional activity of}

\section{R269C-ER compared to WT-ER in breast and pancreatic}

\section{cancer cells}

In order to study the transcriptional activity of R269CER, we generated ER harboring the R269C substitution. Expression of R269C-ER in pancreatic cancer cells was similar to that of overexpressed WT-ER (Supplementary Fig. S1A, B, Additional file 1). The vitellogenin-based ERE-luciferase reporter was then used to study its transcriptional activity, compared to the WT-ER [40]. For the analysis, MCF-7 breast cancer cells, COLO-357 and PANC-1 pancreatic cancer cells and the non-cancerous HEK-293 cells were co-transfected with the reporter and either WT-ER or R269C-ER, grown in estrogen-depleted medium and treated with either vehicle control or E2. R269C-ER demonstrated significantly increased ERE activity compared to WT-ER in all four cell lines, either with or without E2 treatment (Fig. 2, panels a-d). In COLO-357 cells, R269C-ER increased ERE activity by $41 \%$ compared to WT-ER and with E2 treatment the mutant increased it by $22 \%$ (Fig. $2 \mathrm{a}, p<0.01$ ). In PANC1 cells the mutant-ER activity was increased by $44 \%$ compared to WT-ER (Fig. 2b, $p<0.05$ ). In MCF-7 cells, R269C-ER increased the activity, with or without E2 treatment, by 61 and 114\%, respectively (Fig. 2c, $p<$ 0.01). Finally, in HEK-293 the mutation increased the activity by $93 \%$ (Fig. 2 d, $p<0.01$ ) and by only $16 \%$ with E2 treatment (Fig. $2 \mathrm{~d}, p<0.05$ ).

In order to further validate the transcriptional activity of R269C-ER, we examined its ability to induce transcription of the classic estrogen-regulated genes GREB1 and TGF- $\alpha$, which their promoter contains ERE sequences [40]. Surprisingly, while overexpression of R269C-ER in MCF-7 cells decreased mRNA levels of GREB 1 by $31 \%$, and TGF- $\alpha$ by $25 \%$, and also significantly reduced the response to E2 treatment (Fig. 3a, b, $p<0.05$ for all comparisons), it enhanced GREB and TGF- $\alpha$ mRNA levels in COLO-357 cells in response to E2 (Fig. 3c, d, $p<0.01$ ). These data indicate complex, cell-type dependent transcriptional activity of both WTER and R269C-ER in pancreatic cancer cells.

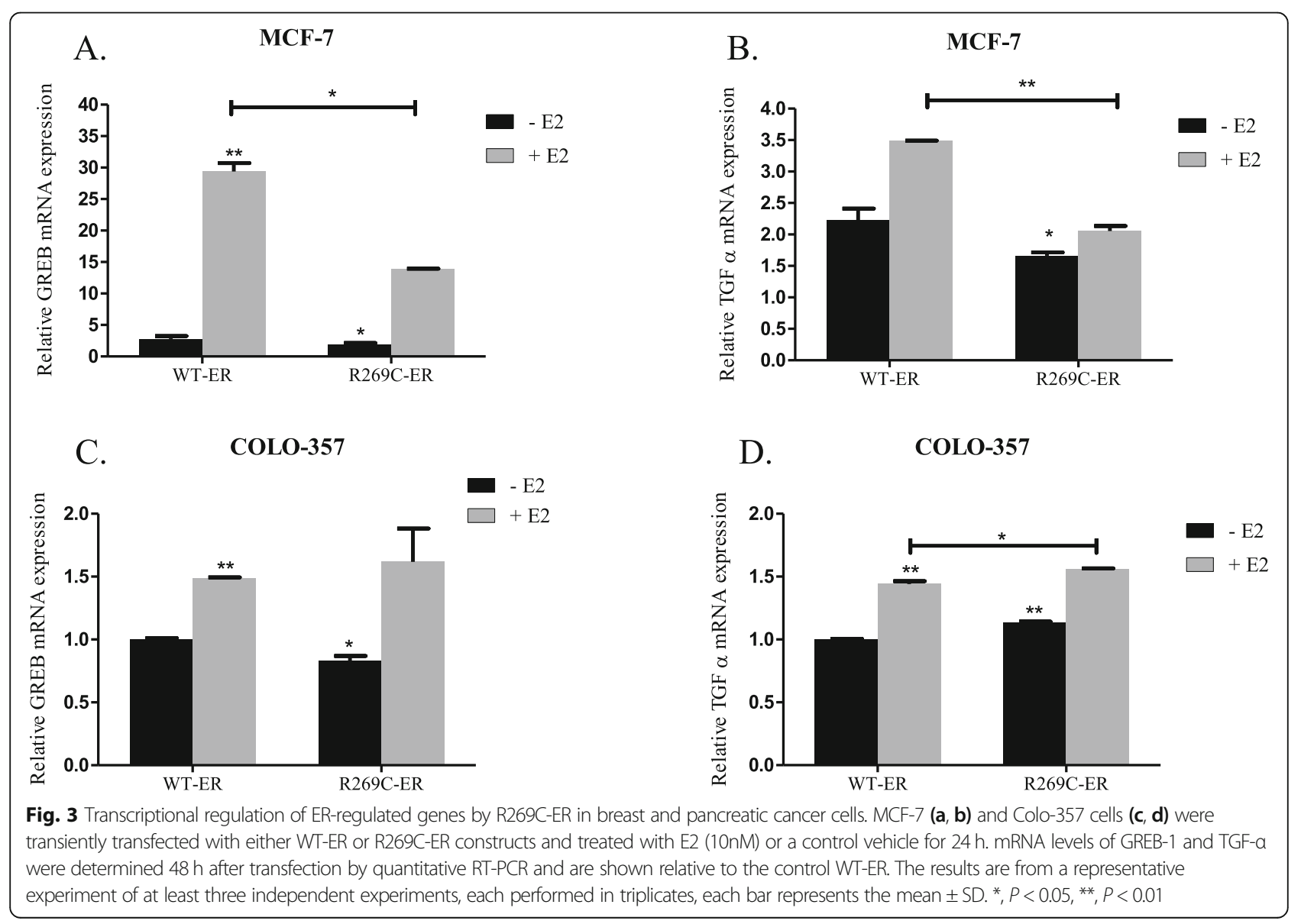


R269C-ER enhances AP-1 dependent transcriptional activity in breast and pancreatic cancer cells

The hinge region has been suggested to mediate nonclassical transcription through interaction with the AF-1 domain and with transcription factors regulating AP-1 activity (e.g. c-Fos/c-Jun, Sp1). In order to analyze the effects of R269C-ER on AP-1 activity, an AP-1-luciferase reporter was employed [41]. COLO-357, PANC-1, MCF7 and HEK-293 cells were co-transfected with the AP-1reporter and either WT-ER or R269C-ER. Cells were grown in estrogen-depleted medium with or without fulvestrant (ICI 182,780), which due to its AP-1 agonist activity, served as a positive control [42, 43, 54]. In comparison to WT-ER, in COLO-357 cells, R269C-ER increased AP-1 transcriptional activity by $48 \%$, in PANC-1 cells by $27 \%$, in MCF-7 cells by $74 \%$ and in HEK-293 cells by $49 \%$ (Fig. 4a-d, $p<0.05$ for all comparisons).

Next, the effect of R269C-ER on the transcription of the AP-1-regulated genes was examined. Expression of R269C-ER in COLO-357 cells increased mRNA levels of both cyclin D1 and IGF-1R by 60 and 65\%, respectively (Fig. 5a-b, $p<0.01$ ). Similarly, in PANC-1 cells we observed an increase of cyclin D1 and IGF-1R mRNA by
64 and $62 \%$, respectively (Fig. $5 c-d, p<0.01$ ). While statistically significant, the effect of R269C-ER on MCF-7 cells was less pronounced: it decreased the levels of cyclin D1 by $25 \%$, and increased levels of IGF-1 by $25 \%$ (Fig. 5e-f, $p<0.05$ ). Taken together, these data indicate AP-1 mediated transcriptional activity of R269C-ER, which is more profound in pancreatic cancer cells compared to breast cancer cells.

\section{Global transcriptomic analysis reveals cell-type} dependent effect of R269C-ER in breast and pancreatic cancer cells

In order to further delineate the transcriptional activity of 269C-ER, a global transcriptomic analysis of MCF-7 and COLO-357 cells expressing either R269C-ER or the WT-ER was performed. Compared to WT-ER, expression of R269C-ER in MCF-7 resulted in differential regulation of 135 genes (44 upregulated, 91 downregulated) with most upregulated genes associated with cell metabolism and hormone biosynthesis (Fig. 6a, b). Interestingly, when treated with E2, an independent set of 61 genes was differentially regulated, with only 3 genes shared with untreated cells (Fig. 6b). Similar analysis of COLO-357 cells indicated differential regulation of 15

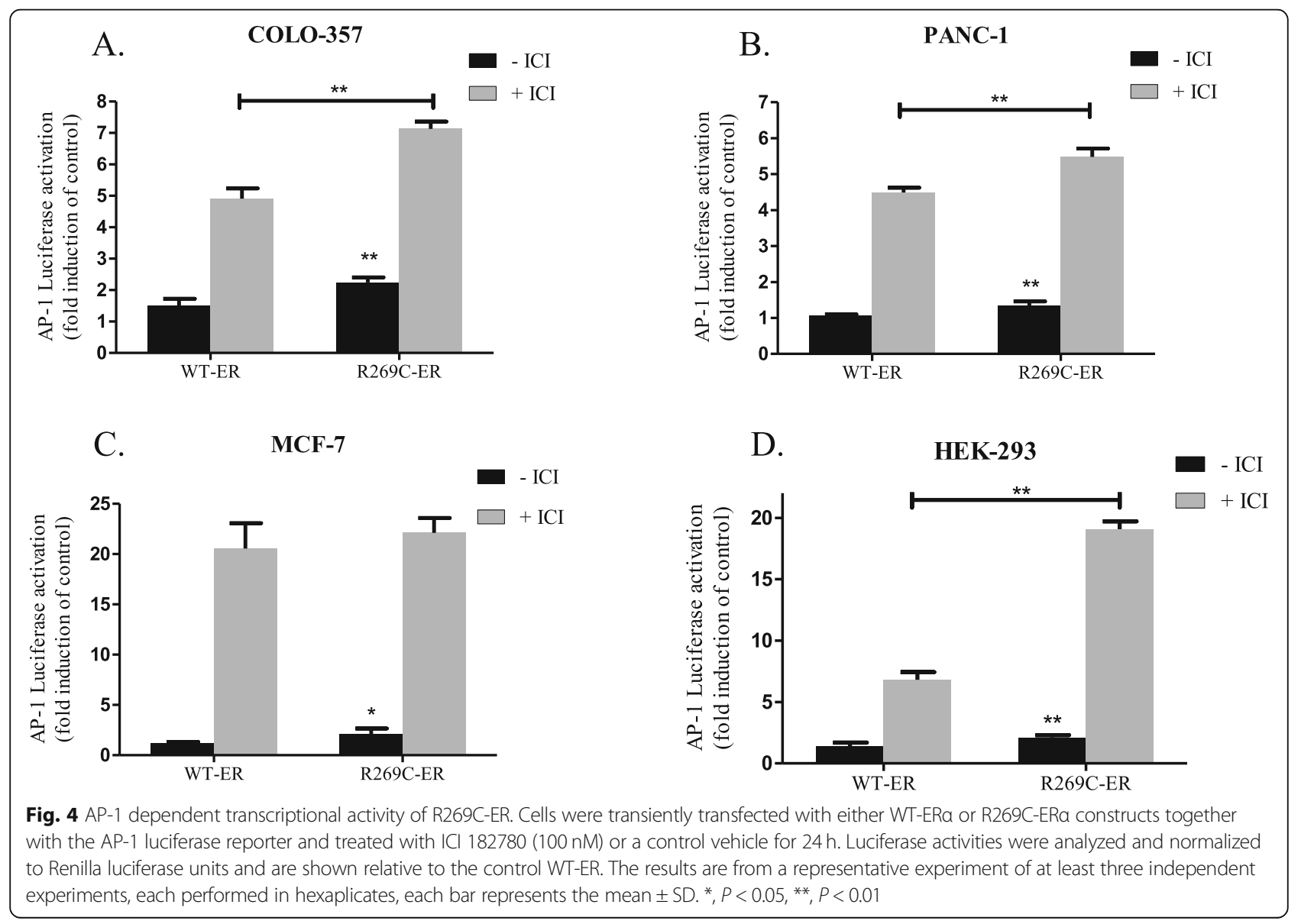




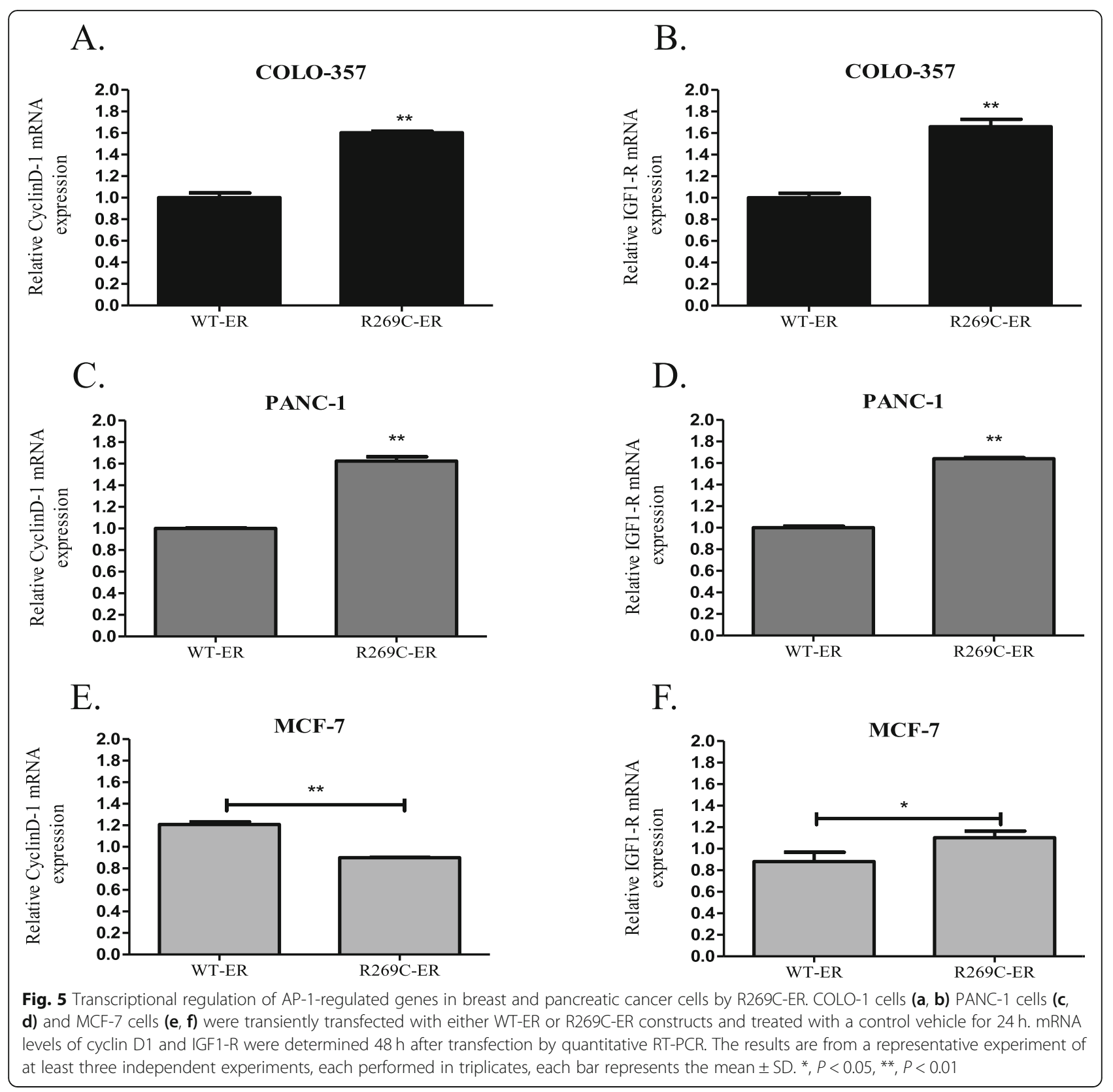

and 45 genes in untreated and E2-treated cells, respectively, with eight genes common to the two groups (Fig. $6 \mathrm{~d}$, e). Importantly, genes regulated by R269C-ER in COLO-357 cells were associated with a more aggressive behavior (Fig. 6e). As we focused on the effect of R269C-ER on pancreatic cancer, we searched for genes known to play a role specifically in this type of cancer. We observed a 6-fold decrease in VASN gene expression (Fig. 2S), a gene involved in the TGF $\beta$ pathway, as evidenced by String analysis (Fig. 7a). Thus, we assessed TGF $\beta 1$ mRNA expression and found it decreased in R269C-ER expressing cells upon E2 treatment compared to WT-ER $(p<0.01$, Fig. $7 \mathrm{~b})$. As TGF $\beta 1$ may play suppressive role in pancreatic cancer development [55, 56], inhibition of this pathway, may be a possible mechanism by which R269C-ER mediates aggressive behavior of pancreatic cancer cells.

\section{R269C-ER enhances migration of pancreatic but not of breast cancer cells}

The effects of R269C-ER on proliferation of MCF-7, COLO-357 and PANC-1 cells were evaluated using MTT assay. For the analysis, cells were transfected with WT-ER or R269C-ER, grown in estrogen-depleted medium, and treated with either a vehicle control or E2. While R269C-ER enhanced proliferation of COLO-357 


\section{$\underline{\text { MCF-7 }}$}

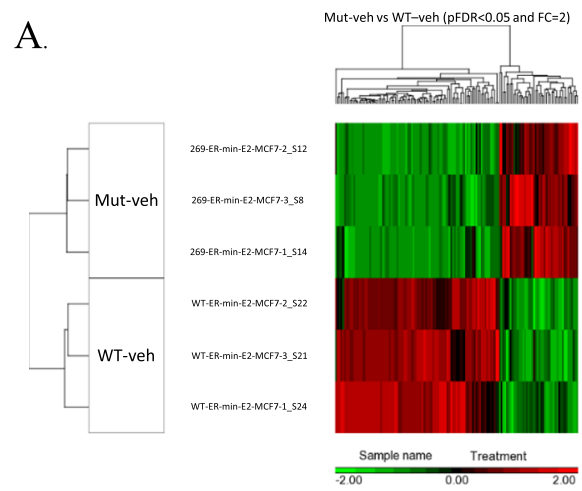

C.

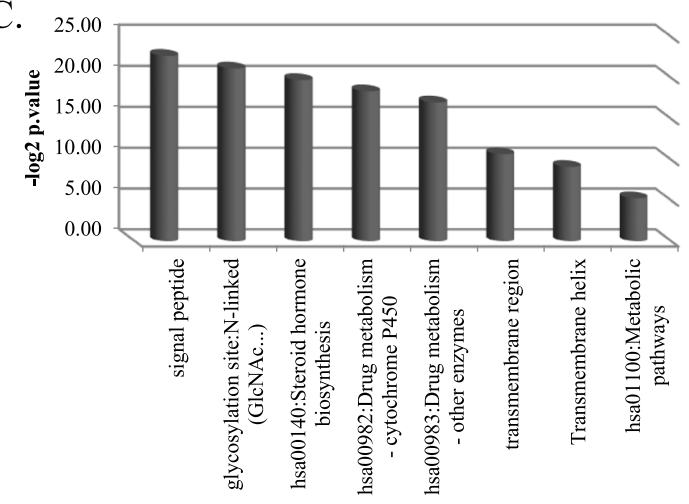

B.

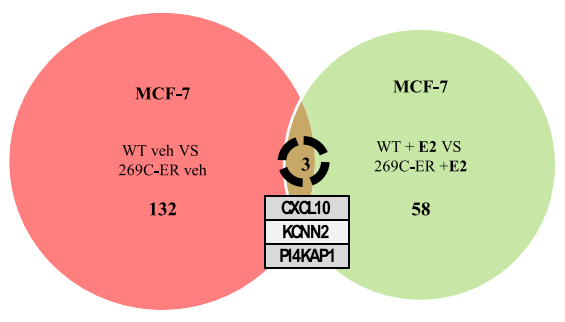

$\underline{\text { COLO-357 }}$

D.
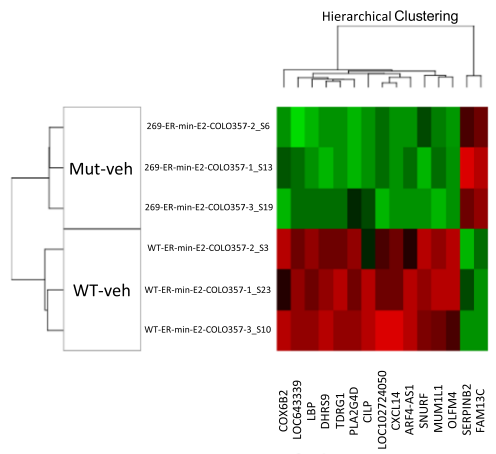

E.

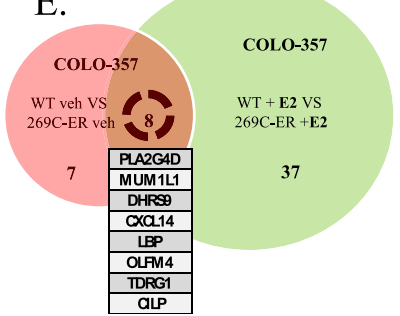

Fig. 6 R269C-ER exhibits differential effect on gene expression in pancreatic cancer cells compared to breast cancer MCF-7 and COLO-357 cells were seeded in phenol red depleted medium with charcoal stripped serum. Cells then were transfected with either WT-ER or R269C-ER in triplicates and then treated with vehicle control or E2 (10nM) for $24 \mathrm{~h}$. Total RNA was extracted and RNAseq was performed. a A heatmap of differentially expressed genes, between untreated mutated and WT-ER, in MCF-7 cells was generated. b A Venn-diagram of significantly $(p<0.05)$ upregulated or downregulated genes in MCF-7 compared to MCF-7 cells treated with E2 is depicted. c Pathway enrichment analysis was conducted in MCF-7 cells treated with E2 (10nM), using Gene Analytics ${ }^{\text {TM}}$. Results show that R269C-ER overexpression is associated with different metabolic pathways. $\mathbf{d}$ A heatmap of differentially expressed genes, between untreated mutated and WT-ER, in COLO-357 cells was generated e A Venn-diagram of significantly $(p<0.05)$ upregulated or downregulated genes in COLO-357 compared to COLO-357 treated with E2 is depicted

in the basal state by $149 \%$ (Fig. $8 \mathrm{a}, p<0.01$ ) and in PANC-1 by $16 \%$ (Fig. $8 \mathrm{~b}, p=0.03$ ). In contrary, it significantly decreased proliferation of MCF-7 cells by $12 \%$ (Fig. 8c, $p=0.02$ ).

The ability of R269C-ER to enhance migration was assessed by wound healing assay. Expression of R269CER significantly enhanced migration of COLO-357 cells compared to WT-ER both after $24 \mathrm{~h}$ and $48 \mathrm{~h}$ by 123 and $90 \%$, respectively, and with E2 treatment by 45 and $58 \%$, respectively (Fig. 9a, $p<0.01$ ). Similar results were observed with E2-untreated PANC-1 cells, after $24 \mathrm{~h}$ the migration was enhanced by $37 \%$ and after 48 h by $25 \%$ (Fig. 9b, $p<0.01$ and $p<0.05$, respectively). However, the mutation did not increase migration of MCF-7 cells, but rather slowed migration compared to WTexpressing cells (Fig. 9c).

\section{Discussion}

While early works suggested a possible role for ER- $\alpha$ in the development of pancreatic cancer $[16-19,57,58]$, its 
A.

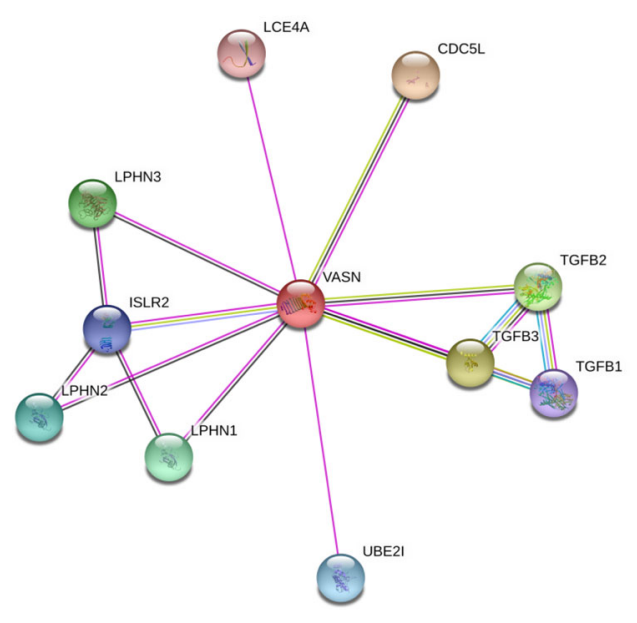

$\underline{\text { MCF-7 }}$

COLO-357

B.
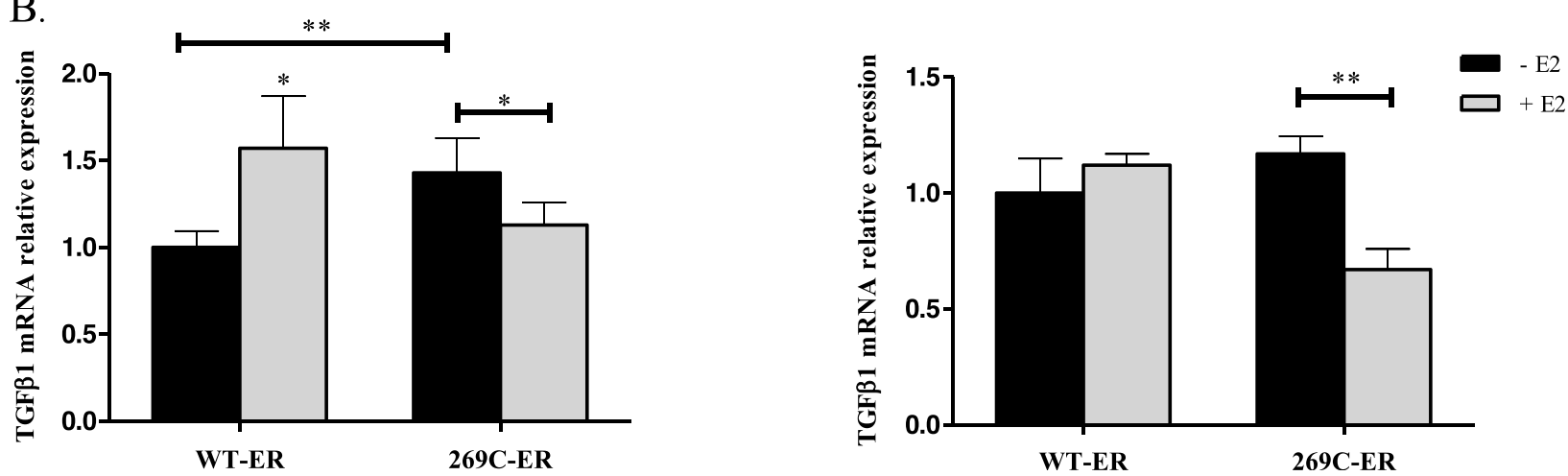

Fig. 7 R269C-ER decreases TGF $\beta$ expression in pancreatic cancer. a A string analysis of VASN gene is depicted. b MCF-7 and COLO-357 cells were seeded in phenol red depleted medium with charcoal stripped serum. Cells then were transfected with either WT-ER or R269C-ER in triplicates and treated with vehicle control or E2 (10nM) for $24 \mathrm{~h}$. Total RNA was extracted and expression of TGF $\beta 1$ was assessed. Each graph represents \pm SD. ${ }^{*}, P<0.05,{ }^{* *}, P<0.01$. Representative experiment is shown

role in the development of this cancer is still controversial. To our knowledge, this is the first report to identify a possible link between this rare variant of the ER and pancreatic cancer development. While this variant is not common, the possibility of treating even a small subset of pancreatic cancer patients with hormonal therapy, which is definitely less toxic and possibly more effective than standard chemotherapy, may be of great value to patients. In addition, our study highlights for the first time, mechanistic aspects of ER activation related to the structure of the hinge region, a much less studied region of the ER, and suggests a role for this region in mediating AP-1 transcriptional activity.

We sought to examine the prevalence and activity of R269C-ER, a rare functional variant of ESR1, in breast and pancreatic cancers. Analysis of a large genomic database indicated enrichment of this variant in a small subset of non-PDAC pancreatic cancers, and functional analysis suggested cell-type dependent activity of this variant. Thus, it showed increased classic and AF-1-mediated transcriptional activity specifically in pancreatic cancer cells while less in MCF-7 breast cancer cells and accordingly enhanced proliferation and migration only of pancreatic cancer cells. A transcriptomic analysis further corroborated these results.

Pancreatic tumors are diverse in histological, molecular and biological features. Both COLO-357 and PANC1 originate from patients with PDAC, but the phenotype and genotype of those cell lines are different. The phenotype of COLO-357 cells remains unknown [59] while the genotype grade (G) is classified as G1-G2 [60]. For PANC-1 cells the phenotype is depict as ductal/acinar [59], and the genotype is classified as G3 [61]. The features of those cell lines are useful in understanding and evaluating the mutation impact on pancreatic cancer, though should be carefully addressed, as there is 


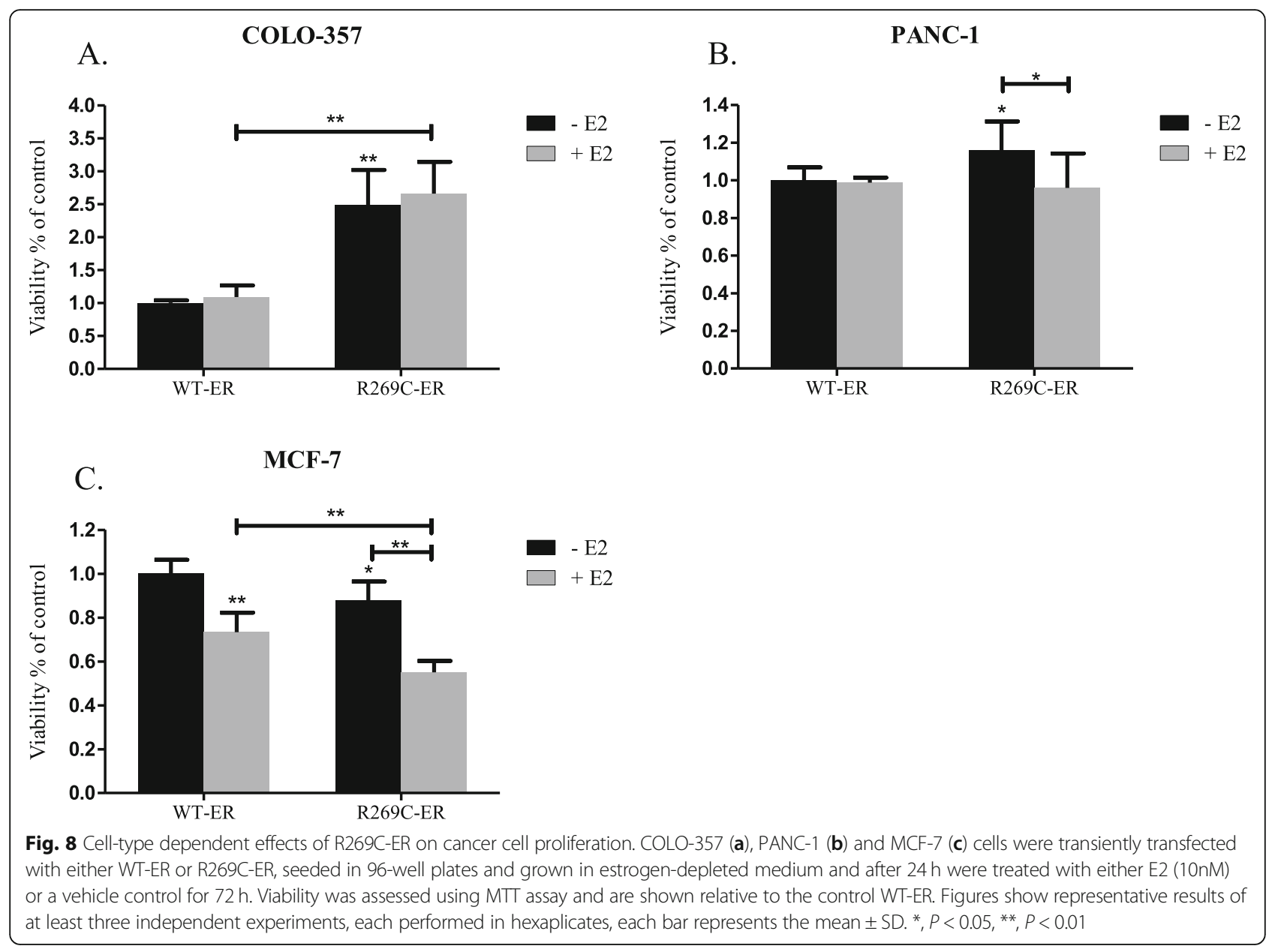

much heterogeneity even within the tumor characteristic. Furthermore, we used ER-positive breast cancer cells (MCF-7) for deeper understanding of the mutation and in effort to examine cells that their tumorgenicity depends on the ER pathway.

R269 lies within the hinge region of ESR1, a region that has not been studied extensively. Position 269 is highly conserved across species as arginine or lysine and lies within a putative NLS region. Substitution of arginine (a conserved negative charge) to cysteine is expected to alter its interactions with both AF-1 and AF-2. In silico study via multiple bioinformatics tools (Polyphen2, SIFT and PROVEAN), predicted with high probability that R269C substitution may damage the structurefunction of this protein [62].

In agreement with these predictions, our data indicates altered transcriptional activity of the variant compared to the WT receptor, an effect that was even more pronounced toward AF-1 than toward AF-2. These observations point to an important role of the hinge region in maintaining proper transcriptional activity of the ER and may explain the low frequency of alterations observed in this area in the general population and among species. We noted a discrepancy between direct transcriptional activity of R269C-ER, as determined using the ERE reporter, and the effect on mRNA of ERE-regulated genes in MCF-7 cells. This observation suggests a role for additional, possibly non-genomic mechanisms regulating the activity of R269C-ER specifically in these cells. The mutation lies within putative NLS2 and possibly affects the activity of the receptor by modifying its subcellular localization, however nuclear and cytoplasmic localization were not disrupted compared to WT-ER (data is not shown).

Surprisingly, the effect of $\mathrm{R} 269 \mathrm{C}$ variant was cell type specific. It inhibited gene expression, proliferation and migration of MCF-7 cells. The precise upstream regulatory elements leading to these differential effects are yet to be determined. This observation explains the lack of enrichment of R269C among breast cancer patients. Thus, expression of $\mathrm{R} 269 \mathrm{C}$ is probably not associated with increased breast cancer risk. On the other hand, expression of R269C had profound effect on pancreatic cancer cells. 


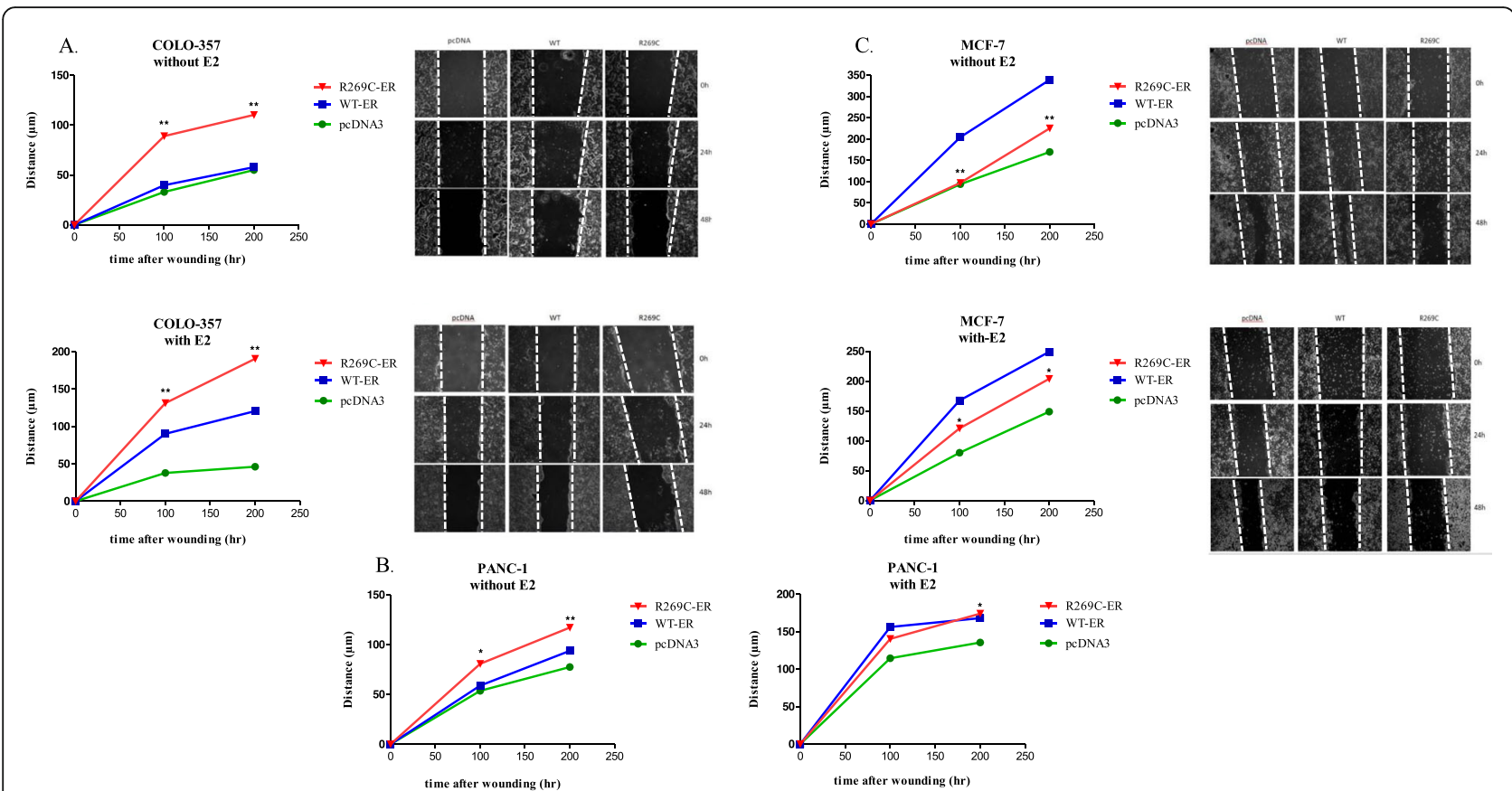

Fig. 9 R269C-ER enhances migration of pancreatic cancer cells. COLO-357 (a) PANC-1 (b) and MCF-7 (c) were seeded in 6-well plates and transfected with either WT-ER, R269C-ER or pcDNA3 constructs. Cells were grown in estrogen-depleted medium and the monolayer was scraped in a straight line, then treated with E2 (10nM) or a vehicle control for $48 \mathrm{~h}$. The results are from a representative experiment of at least three independent experiments. Mean values of at least 10 measurements for each time point and condition are shown on the graphs and representative photos are also presented, ${ }^{*}, P<0.05,{ }^{*}, P<0.01$

It enhanced transcriptional activity of both classical and AF-1-regulated genes, enhanced proliferation and promoted migration of two pancreatic cancer cell lines. These observations may explain the enrichment of $\mathrm{R} 269 \mathrm{C}$ among a subset of pancreatic cancers. It also highlights the need to study the effects of this mutation in additional pancreatic cancer subtype models.

A global transcriptome analysis, using RNAseq, indicated differential gene expression among breast and pancreatic cancer cell lines expressing the mutated ER. Thus, expression of the R269C-ER was associated with ligand-independent upregulation of genes associated with cell metabolism and hormone biosynthesis, and not with growth or invasion. This observation may explain the lack of association between the presence of this SNP and increase breast cancer risk. On the one hand, alterations of genes associated with tumorogenicity were observed in COLO-357 cells. These included upregulation SERPINB2, a known oncogene [63-65], and a decrease in TGF $\beta 1$ expression, a cytokine which may function under specific circumstances as a tumor suppressor in pancreatic cancer [66-68]. Indeed, Hezel et al. showed that TGF- $\beta$ or $\alpha \mathrm{v} \beta 6$ blockade increased pancreatic tumor cell proliferation and accelerated both early and later disease stages [55]. Importantly, these observations indicate, for the first time, a direct role of the hinge region in regulating transcriptional activity of the ER.

Previous studies, published mostly during the 1980s and 1990s, explored the role of anti-estrogens as a potential treatment for pancreatic cancer. While preclinical studies were promising [69], clinical trials showed conflicting results, partly due to under power of the trials and partly may be attributed to the inclusion of all pancreatic cancer patients, regardless expression of the ER or the presence of functional variants. Importantly, while our study indicated increased activity of this variant, at least part of the increased activity is mediated through the AF-1 and is E2 independent. Therefore, it is likely that current hormonal therapies targeting the ER, either by reducing estrogen levels (aromatase inhibitors) or by inhibition of its classic activity (tamoxifen) may not be effective and other manipulations should be examined. The frequency of the variant, even among non-PDAC patients is low $(\sim 0.5 \%)$. Therefore, the conduction of clinical trials on this specific patients' population is likely to be very challenging. Yet, considering the grim prognosis and limited treatment options for patients with pancreatic cancer, the ability to target even a small fraction of patients is of major significance. 


\section{Conclusion}

Our data suggest a role for R269C functional variant of the ESR1 in the development of a small subset of nonPDAC pancreatic cancers. Moreover, our data suggest that this variant may have a protective effect against breast cancer. The underlying mechanism should be further explored.

\section{Supplementary information}

Supplementary information accompanies this paper at https://doi.org/10. 1186/s12885-020-07005-x.

Additional file 1: Figure S1. Expression of R269C-ER in pancreatic cancer cells. PANC-1 (A) or COLO-357 (B) cells were transfected with either PCDNA3, WT-ER or R269C-ER grown in estrogen-depleted medium and treated with E2 (10nM) or a control vehicle for $24 \mathrm{~h}$. Cells were harvested, lysed and analyzed by Western blotting. The results of $(\mathbf{A})$ and $(\mathbf{B})$ are from a representative experiment of $n=3$.

Additional file 2: Figure S2. R269C-ER exhibits differential effect following E2 treatment on gene expression in pancreatic cancer cells. A list of genes down and upregulated by R269C-ER compared to WT-ER following E2 treatment in COLO-357 cells.

Additional file 3: Figure S3. R269C-ER exhibits differential effect on gene expression in pancreatic cancer cells compared to breast cancer. MCF-7 and COLO-357 cells were seeded in phenol red depleted medium with charcoal stripped serum. Cells then were transfected with either WTER or R269C-ER in triplicates and then treated with vehicle control or E2 (10nM) for $24 \mathrm{~h}$. Total RNA was extracted and RNAseq was performed. (A, B) A heatmap of differentially expressed genes in MCF-7 cells treated with E2 (A) and COLO-357 cells treated with E2 (B) was generated.

\section{Abbreviations \\ AF-1: Activation Function-1; AF-2: Activation Function-2; DBD: DNA-binding domain; $E_{2}$ : 17ß-Estradiol; ECL: Enhanced chemiluminescence; ERE: E2- response elements; ESR1: Estrogen receptor a (ESR1); G: Grade; HRP: Horse raddish peroxidase; LBD: Ligand-binding domain; MSA: Multiple Sequence Alignment; NLS: Nuclear localization sequence; PDAC: Pancreatic ductal adenocarcinoma; R269C: Substitution of arginine to cysteine at position 269 of the hinge region; RIPA: Radio-immunoprecipitation assay}

\section{Acknowledgements}

Not applicable.

\section{Authors' contributions}

TB and KML-Collected the data, performed the analysis of in vitro assays, and wrote the paper. SJ-Collected the data, performed the analysis of in vitro assays. ES- Collected the data, performed the analysis of in vitro assays. DL- Conceived and designed the analysis, collected the data, contributed data and analysis tools, performed analysis, and participated in writing of the paper. AY- Contributed analysis tools, analyzed the three dimensional protein structure and participated in writing of the paper. MPCContributed data and analysis tools, performed analysis of RNA sequencing, and participated in writing. TR- Conceived and designed the analysis, collected the data, performed analysis, and wrote the paper. IW- Conceived and designed the analysis, collected the data, performed analysis, and wrote the paper. All authors read and approved the final manuscript.

\section{Funding}

This work was financially supported by the Israel Science Foundation to I.W (grant no. 1320/14); the Israel Cancer Association to I.W. (grant no. 20160053); The Margaret Stultz foundation, the Sackler Faculty of Medicine, Tel Aviv University, Tel Aviv, Israel; and TASMC excellence fund. The funding sources had no implications on the study design, collections, analysis, and interpretation of data or writing the manuscript.

\section{Availability of data and materials}

The datasets used and/or analyzed during the current study are available from the corresponding author on reasonable request.

Ethics approval and consent to participate

Not applicable.

\section{Consent for publication}

Not applicable.

\section{Competing interests}

IW reports receiving speakers bureau honoraria and is a consultant/advisory board member for Roche. The other authors declare that they have no competing interests.

\section{Author details}

${ }^{1}$ Institute of Oncology, Tel Aviv Sourasky Medical Center, 6423906 Tel Aviv, Israel. ${ }^{2}$ Sackler Faculty of Medicine, Tel Aviv University, 6997801 Tel Aviv, Israel. ${ }^{3}$ Foundation Medicine, Inc., Cambridge, MA 02141, USA. ${ }^{4}$ The Bioinformatics Unit, George S. Wise Faculty of Life Sciences, Tel Aviv University, 6997801 Tel Aviv, Israel.

Received: 18 November 2019 Accepted: 26 May 2020

Published online: 08 June 2020

References

1. Ascenzi P, Bocedi A, Marino M. Structure-function relationship of estrogen receptor alpha and beta: impact on human health. Mol Asp Med. 2006;27: 299-402.

2. Klinge CM. Estrogen receptor interaction with co-activators and corepressors. Steroids. 2000;65:227-51.

3. Burns KA, Li Y, Liu L, Korach KS. Research resource: comparison of gene profiles from wild-type ERalpha and ERalpha hinge region mutants. Mol Endocrinol. 2014:28:1352-61.

4. Subramanian K, Jia D, Kapoor-Vazirani P, Powell DR, Collins RE, Sharma D, et al. Regulation of estrogen receptor alpha by the SET7 lysine methyltransferase. Mol Cell. 2008;30:336-47.

5. Fu M, Wang C, Reutens AT, Wang J, Angeletti RH, Siconolfi-Baez $L$, et al. p300 and p300/cAMP-response element-binding protein-associated factor acetylate the androgen receptor at sites governing hormone-dependent transactivation. J Biol Chem. 2000;275:20853-60.

6. Sentis S, Le Romancer M, Bianchin C, Rostan M-C, Corbo L. Sumoylation of the estrogen receptor alpha hinge region regulates its transcriptional activity. Mol Endocrinol. 2005;19:2671-84.

7. Jemal A, Bray F, Center MM, Ferlay J, Ward E, Forman D. Global cancer statistics. CA Cancer J Clin. 2011;61:69-90.

8. Marquez-Garban DC, Mah V, Alavi M, Maresh EL, Chen H-W, Bagryanova L, et al. Progesterone and estrogen receptor expression and activity in human non-small cell lung cancer. Steroids. 2011;76:910-20.

9. $\quad$ Tang W, Liu R, Yan Y, Pan X, Wang M, Han X, et al. Expression of estrogen receptors and androgen receptor and their clinical significance in gastric cancer. Oncotarget. 2017:8:40765-77.

10. Campbell-Thompson M, Lynch IJ, Bhardwaj B. Expression of estrogen receptor (ER) subtypes and ERbeta isoforms in colon cancer. Cancer Res. 2001;61:632-40.

11. Siegel RL, Miller KD, Jemal A. Cancer statistics, 2017. CA Cancer J Clin. 2017; 67:7-30.

12. Lowenfels $A B$, Maisonneuve P. Epidemiology and risk factors for pancreatic cancer. Best Pract Res Clin Gastroenterol. 2006;20:197-209.

13. Amundadottir LT. Pancreatic cancer genetics. Int J Biol Sci. 2016;12:314-25.

14. Makohon-Moore A, lacobuzio-Donahue CA. Pancreatic cancer biology and genetics from an evolutionary perspective. Nat Rev Cancer. 2016;16:553-65.

15. Hamilton S.R. ALA. (Eds.): World Health Organization classification of tumours. Pathology and genetics of tumours of the digestive system https://www.iarc.fr/ en/publications/pdfs-online/pat-gen/bb2/bb2-chap10.pdf.

16. Ishida K, Sasano H, Moriya T, Takahashi Y, Sugimoto R, Mue Y, et al. Immunohistochemical analysis of steroidogenic enzymes in ovarian-type stroma of pancreatic mucinous cystic neoplasms: comparative study of subepithelial stromal cells in intraductal papillary mucinous neoplasms of the pancreas. Pathol Int. 2016;66:281-7. 
17. Izumo A, Yamaguchi K, Eguchi T, Nishiyama K, Yamamoto H, Yonemasu H, et al. Mucinous cystic tumor of the pancreas: immunohistochemical assessment of "ovarian-type stroma". Oncol Rep. 2003;10:515-25.

18. Iwao K, Miyoshi Y, Ooka M, Ishikawa O, Ohigashi H, Kasugai T, et al. Quantitative analysis of estrogen receptor-alpha and -beta messenger RNA expression in human pancreatic cancers by real-time polymerase chain reaction. Cancer Lett. 2001;170:91-7.

19. Satake M, Sawai H, Go VLW, Satake K, Reber HA, Hines OJ, et al. Estrogen receptors in pancreatic tumors. Pancreas. 2006;33:119-27.

20. Robinson EK, Grau AM, Evans DB, Smid CM, Chiao PJ, Abbruzzese JL, et al. Cell cycle regulation of human pancreatic cancer by tamoxifen. Ann Surg Oncol. 1998;5:342-9.

21. Greenway B, Duke D, Pym B, lqbal MJ, Johnson PJ, Williams R. The control of human pancreatic adenocarcinoma xenografts in nude mice by hormone therapy. Br J Surg. 1982;69:595-7.

22. Tonnesen K, Kamp-Jensen M. Antiestrogen therapy in pancreatic carcinoma: a preliminary report. Eur J Surg Oncol. 1986;12:69-70.

23. Wong A, Chan A, Arthur K. Tamoxifen therapy in unresectable adenocarcinoma of the pancreas. Cancer Treat Rep. 1987;71:749-50.

24. Horimi T, Takasaki M, Toki A, Nishimura W, Morita S. The beneficial effect of tamoxifen therapy in patients with resected adenocarcinoma of the pancreas. Hepatogastroenterology. 1996;43:1225-9.

25. Theve NO, Pousette A, Carlstrom K. Adenocarcinoma of the pancreas--a hormone sensitive tumor? A preliminary report on Nolvadex treatment. Clin Oncol. 1983:9:193-7.

26. Wong A, Chan A. Survival benefit of tamoxifen therapy in adenocarcinoma of pancreas. A case-control study. Cancer. 1993;71:2200-3.

27. Tomao S, Romiti A, Massidda B, lonta MT, Farris A, Zullo A, et al. A phase II study of gemcitabine and tamoxifen in advanced pancreatic cancer. Anticancer Res. 2002;22:2361-4.

28. Bakkevold KE, Pettersen A, Arnesjo B, Espehaug B. Tamoxifen therapy in unresectable adenocarcinoma of the pancreas and the papilla of Vater. $\mathrm{Br} \mathrm{J}$ Surg. 1990;77:725-30.

29. Keating JJ, Johnson PJ, Cochrane AM, Gazzard BG, Krasner N, Smith PM, et al. A prospective randomised controlled trial of tamoxifen and cyproterone acetate in pancreatic carcinoma. Br J Cancer. 1989;60:789-92.

30. Taylor OM, Benson EA, McMahon MJ. Clinical trial of tamoxifen in patients with irresectable pancreatic adenocarcinoma. The Yorkshire gastrointestinal tumour group. Br J Surg. 1993;80:384-6.

31. Frampton GM, Fichtenholtz A, Otto GA, Wang K, Downing SR, He J, et al. Development and validation of a clinical cancer genomic profiling test based on massively parallel DNA sequencing. Nat Biotechnol. 2013;31:1023-31.

32. Kieslich CA, Smadbeck J, Khoury GA, Floudas CA. conSSert: consensus SVM model for accurate prediction of ordered secondary structure. J Chem Inf Model. 2016;56:455-61.

33. Buchan DWA, Minneci F, Nugent TCO, Bryson K, Jones DT. Scalable web services for the PSIPRED protein analysis workbench. Nucleic Acids Res. 2013;41(Web Server issue):W349-57.

34. Cole C, Barber JD, Barton GJ. The Jpred 3 secondary structure prediction server. Nucleic Acids Res. 2008;36(Web Server issue):W197-201.

35. Frishman D, Argos P. Incorporation of non-local interactions in protein secondary structure prediction from the amino acid sequence. Protein Eng. 1996:9:133-42.

36. Kuraku S, Zmasek CM, Nishimura O, Katoh K. aLeaves facilitates on-demand exploration of metazoan gene family trees on MAFFT sequence alignment server with enhanced interactivity. Nucleic Acids Res. 2013;41(Web Server issue):W22-8

37. Waterhouse AM, Procter JB, Martin DMA, Clamp M, Barton GJ. Jalview version 2--a multiple sequence alignment editor and analysis workbench. Bioinformatics. 2009;25:1189-91.

38. Finn RD, Coggill P, Eberhardt RY, Eddy SR, Mistry J, Mitchell AL, et al. The Pfam protein families database: towards a more sustainable future. Nucleic Acids Res. 2016;44:D279-85.

39. Merenbakh-Lamin K, Ben-Baruch N, Yeheskel A, Dvir A, Soussan-Gutman L, Jeselsohn $\mathrm{R}$, et al. D538G mutation in estrogen receptor-alpha: a novel mechanism for acquired endocrine resistance in breast cancer. Cancer Res. 2013;73:6856-64.

40. Fan S, Wang J, Yuan R, Ma Y, Meng Q, Erdos MR, et al. BRCA1 inhibition of estrogen receptor signaling in transfected cells. Science. 1999;284:1354-6.

41. Burns KA, Li Y, Arao Y, Petrovich RM, Korach KS. Selective mutations in estrogen receptor alpha D-domain alters nuclear translocation and non- estrogen response element gene regulatory mechanisms. J Biol Chem. 2011;286:12640-9.

42. Jakacka M, Ito M, Weiss J, Chien PY, Gehm BD, Jameson JL. Estrogen receptor binding to DNA is not required for its activity through the nonclassical AP1 pathway. J Biol Chem. 2001;276:13615-21.

43. Kushner PJ, Agard DA, Greene GL, Scanlan TS, Shiau AK, Uht RM, et al. Estrogen receptor pathways to AP-1. J Steroid Biochem Mol Biol. 2000;74: $311-7$.

44. Wolf I, Levanon-Cohen S, Bose S, Ligumsky H, Sredni B, Kanety H, et al. Klotho: a tumor suppressor and a modulator of the IGF-1 and FGF pathways in human breast cancer. Oncogene. 2008;27:7094-105.

45. Partek Flow. http://www.partek.com/partek-flow/. Accessed 10 May 2019.

46. Li H, Durbin R. Fast and accurate short read alignment with burrowswheeler transform. Bioinformatics. 2009;25:1754-60.

47. Xing Y, Yu T, Wu YN, Roy M, Kim J, Lee C. An expectation-maximization algorithm for probabilistic reconstructions of full-length isoforms from splice graphs. Nucleic Acids Res. 2006;34:3150-60.

48. Law CW, Chen Y, Shi W, voom Smyth GK. Precision weights unlock linear model analysis tools for RNA-seq read counts. Genome Biol. 2014;15:R29.

49. Benjamini $Y$, Hochberg Y. Controlling the false discovery rate: a practical and powerful approach to multiple testing. J R Stat Soc Ser B. 1995;57:289300. https://doi.org/10.1111/j.2517-6161.1995.tb02031.x.

50. Partek Genomics Suite. http://www.partek.com/partek-genomics-suite/. Accessed 10 May 2019.

51. dbSNP. https://www.ncbi.nlm.nih.gov/snp/?term=rs142712646. Accessed 24 Jul 2019.

52. Ylikomi T, Bocquel MT, Berry M, Gronemeyer $H$, Chambon P. Cooperation of proto-signals for nuclear accumulation of estrogen and progesterone receptors. EMBO J. 1992;11:3681-94.

53. Picard D, Kumar V, Chambon P, Yamamoto KR. Signal transduction by steroid hormones: nuclear localization is differentially regulated in estrogen and glucocorticoid receptors. Cell Regul. 1990;1:291-9.

54. Webb P, Lopez GN, Uht RM, Kushner PJ. Tamoxifen activation of the estrogen receptor/AP-1 pathway: potential origin for the cell-specific estrogen-like effects of antiestrogens. Mol Endocrinol. 1995;9:443-56.

55. Hezel AF, Deshpande V, Zimmerman SM, Contino G, Alagesan B, O'Dell MR, et al. TGF- $\beta$ and $a v \beta 6$ integrin act in a common pathway to suppress pancreatic cancer progression. Cancer Res. 2012;72:4840-5.

56. Melzer C, Hass R, von der Ohe J, Lehnert $H$, Ungefroren $H$. The role of TGF- $\beta$ and its crosstalk with RAC1/RAC1b signaling in breast and pancreas carcinoma. Cell Commun Signal. 2017;15:19.

57. Greenway B, lqbal MJ, Johnson PJ, Williams R. Oestrogen receptor proteins in malignant and fetal pancreas. Br Med J (Clin Res Ed). 1981;283:751-3.

58. Satake K, Yoshimoto T, Mukai R, Umeyama K. Estrogen receptors in 7,12dimethylbenz (a) anthracene (DMBA) induced pancreatic carcinoma in rats and in human pancreatic carcinoma. Clin Oncol. 1982;8:49-54.

59. Frazier ML, Longnecker DS. Cell lines of the human and rodent exocrine pancreas. In: The pancreas biology, pathobiology, and disease. Second Edi. 1993. p. 565-74. https://journals.Iww.com/pancreasjournal/Documents/ pancreaschapters/the pancreasCh28.pdf.

60. Morgan RT, Woods LK, Moore GE, Quinn LA, McGavran L, Gordon SG. Human cell line (COLO 357) of metastatic pancreatic adenocarcinoma. Int J Cancer. 1980;25:591-8.

61. Sipos B, Moser S, Kalthoff H, Torok V, Lohr M, Kloppel G. A comprehensive characterization of pancreatic ductal carcinoma cell lines: towards the establishment of an in vitro research platform. Virchows Arch. 2003;442:444-52.

62. Rebai M, Rebai A. In silico characterization of functional SNP within the oestrogen receptor gene. J Genet. 2016;95:865-74.

63. Rushworth LK, Kidger AM, Delavaine L, Stewart G, van Schelven S, Davidson J, et al. Dual-specificity phosphatase 5 regulates nuclear ERK activity and suppresses skin cancer by inhibiting mutant Harvey-Ras (HRasQ61L)-driven SerpinB2 expression. Proc Natl Acad Sci U S A. 2014;111:18267-72.

64. Valiente M, Obenauf AC, Jin X, Chen Q, Zhang XH-F, Lee DJ, et al. Serpins promote cancer cell survival and vascular co-option in brain metastasis. Cell. 2014;156:1002-16.

65. Huang Z, Li H, Huang Q, Chen D, Han J, Wang L, et al. SERPINB2 downregulation contributes to chemoresistance in head and neck cancer. $\mathrm{Mol}$ Carcinog. 2014;53:777-86.

66. Shen W, Tao G-Q, Zhang Y, Cai B, Sun J, Tian Z-Q. TGF-beta in pancreatic cancer initiation and progression: two sides of the same coin. Cell Biosci. 2017;7:39. 
67. Syed V. TGF-beta signaling in Cancer. J Cell Biochem. 2016;117:1279-87.

68. Truty MJ, Urrutia R. Basics of TGF-beta and pancreatic cancer. Pancreatology. 2007;7:423-35

69. Konduri S, Schwarz RE. Estrogen receptor beta/alpha ratio predicts response of pancreatic cancer cells to estrogens and phytoestrogens. J Surg Res. 2007;140:55-66

\section{Publisher's Note}

Springer Nature remains neutral with regard to jurisdictional claims in published maps and institutional affiliations.

Ready to submit your research? Choose BMC and benefit from:

- fast, convenient online submission

- thorough peer review by experienced researchers in your field

- rapid publication on acceptance

- support for research data, including large and complex data types

- gold Open Access which fosters wider collaboration and increased citations

- maximum visibility for your research: over $100 \mathrm{M}$ website views per year

At $B M C$, research is always in progress.

Learn more biomedcentral.com/submissions 